\title{
Konteks Politik Hukum Di Balik Percepatan Penetapan Hutan Adat: Catatan Ke Arah Transisi 2019
}

\author{
Oleh: Muki T. Wicaksono ${ }^{1}$ dan Malik $^{2}$
}

\begin{abstract}
Abstrak
Pasca Putusan Mahkamah Konstitusi No.35/PUU-X/2012, tahapan baru bagi masyarakat adat sebagai subjek pengelola hutan adat berdampak positif terhadap transformasi pengelolaan kawasan hutan dan sumber daya alam di Indonesia. Konteks politik-hukum menjadi hal yang penting untuk dipahami secara historis dan kontekstual dalam melihat beragam strategi yang dilakukan oleh NGO dalam mendorong pengakuan bagi masyarakat adat di dalam kawasan hutan. Tulisan ini muncul dari hasil observasi penulis selama kurun waktu 2015-2017 atas arah advokasi NGO pegiat masyarakat adat di Indonesia dalam proses regularisasi tentang hutan adat. Berfokus pada proses regularisasi sebagai proses sosial, tulisan ini menelaah dinamika Pasca keluarnya Putusan MK 35 yang mengoreksi UU No.41/1999 tentang kehutanan, yang kini memposisikan 'hutan adat adalah berada terpisah dari hutan negara'. Dengan memahami proses terbentuknya aturan sebagai sebuah proses sosial, tulisan ini melihat sebuah produk hukum sebagai dokumen yang hidup dan menghasilkan perubahan sosial dalam menempatkan masyarakat adat sebagai subjek pengelola kawasan hutan. Berfokus pada 215

1 Penulis merupakan peneliti di Divisi Riset Sosial dan Ekonomi di Epistema Institute. Sejak tahun 2009 menekuni bidang antropologi di FISIP - Universitas Indonesia, dan melakukan beragam kajian tentang petani, masyarakat lokal, perubahan iklim, dan masyarakat adat di dalam dan sekitar kawasan hutan melalui studi etnografi. (muki.wicaksono@epistema.or.id).

2 Penulis merupakan peneliti di Divisi Hukum dan Agraria di Epistema Institute sejak tahun 2013 dan telah menuliskan beragam kajian socio-legal, terkait aspek hukum adat, hutan adat dan masyarakat adat. Selain itu pengalamannya sebagai legal drafter dalam penyusunan produk hukum daerah tentang MHA menjadi refleksi yang digunakan dalam tulisan ini (malik@epistema.or.id).
\end{abstract}


produk hukum daerah tentang masyarakat adat selama kurun waktu 1979-2017, dan proses penetapan hutan adat oleh Negara, tulisan ini menyimpulkan bahwa pentingnya mendorong proses regularisasi dalam bentuk diskresi yang efektif untuk mengisi kekosongan hukum pada upaya percepatan penetapan hutan adat di Indonesia. Upaya tersebut telah dilakukan oleh NGO pegiat masyarakat adat dengan melakukan sejumlah advokasi untuk mendorong kebijakan di tingkat daerah, kementerian, hingga peraturan perundang-undangan di tingkat nasional. Pada akhir bagian, tulisan ini memperlihatkan salah satu inisiatif NGO dalam mewacanakan konsep Areal Konservasi Kelola Masyarakat (AKKM atau ICCAs) sebagai salah satu strategi untuk melibatkan masyarakat adat dalam pengelolaan kawasan konservasi dengan cara yang berkelanjutan. Selain itu, momentum tahun politik pilkada serentak di tahun 2018, dan Pilpres di tahun 2019, menjadi peluang sekaligus tantangan untuk mendorong masyarakat adat sebagai subjek aktif pengelola kawasan hutan.

Kata Kunci: Diskresi, Hutan Adat, Masyarakat Adat, NGO, Produk Hukum Daerah, dan Proses Regularisasi

\section{Abstract}

After the released of Constitutional Court No.35/PUU-X/2012, a new step for masyarakat adat (indigenous peoples), as an important actor for customary forest management, have provided impact for transformation on forest and natural resources management in Indonesia. Legal-politic context has become the important facet to be assess in historical and contextual. It relates to identify various NGOs' strategy in supporting the recognition of masyarakat adat within state forest areas. This paper is based on authors' observation on NGOs advocacy who concern in legal recognition for adat land in the period 2015-2017, its particularly in process of regularization on gazettement of customary forests. By focusing on process of regularization as social process, this paper is assessing on the dynamic after the enactment of Ruling No.35/2012 which resolved misconceptions on Indonesia's Forestry Law No.41/1999, and it revised to be 'customary forests are no longer a part of state forests but part of the titled forests'. By understanding the process of regularization as social process, this paper want to see the legal product as living document, and it generated social change in positioning masyarakat adat as 
the main subject to manage forest areas. This paper focused on 215 regional legislation product on masyarakat adat in the period 1979-2017, and it compares to the process of gazettement of customary forest by State. This paper concluded that how important to support process of regularization to produce discretion effectively to fill the legal gaps on accelerating the gazettement of customary forests in Indonesia. This effort has conducted by NGOs who support the recognition of masyarakat adat through several advocacy to support policy at regional, ministry, until national regulations. At the end part, this paper want to show one of initiative NGO in introducing approach on Indigenous Peoples and Community Conservation Areas (ICCAs) as one of strategies to involve masyarakat adat in managing conservation areas within sustainable ways. In addition, the political moment in 2018-2019 will very important to take into account in this paper, while government of Indonesia will prepare Regional Election for District and Provincial level, and Presidential Election in 2019. It becomes opportunity and challenge to support masyarakat adat as the main subject to manage forest areas.

Keywords: Customary Forests, Discretion, Masyarakat Adat, NGOs, Process of Regularization, and Regional Legislation Products.

\section{Latar belakang}

“Dari 8,3 juta hektar, kemenangan yang sangat kecil $( \pm 17.000$ hektar bagi hutan adat) tetapi sangat berat, susahnya mencapai hak konstitusi bagi masyarakat adat" - Rukka Sombolinggi, Sekjen Aliansi Masyarakat Adat Nusantara Periode 2017-2022

Kutipan di atas merupakan pernyataan Sekjen AMAN (Aliansi Masyarakat Adat Nusantara) saat menyampaikan hasil Catatan Akhir Tahun lembaga tersebut di tahun 2017. Capaian yang sangat sedikit dibandingkan dengan realitas luas wilayah dan hutan adat di Indonesia. AMAN menjadi lembaga yang konsisten dalam menyuarakan pengakuan terhadap masyarakat adat sejak Kongres Masyarakat Adat Nasional (KMAN I) dilakukan pada tahun 1999. Saat itu pernyataan 'jika Negara tidak mengakui masyarakat adat, kami tidak akan mengakui Negara' menjadi pameo yang banyak disampaikan oleh komunitas adat di Indonesia. Dalam suasana atmosfer demokrasi dan keterbukaan, Kongres Masyarakat Adat pertama membentuk AMAN menjadi organisasi masyarakat 
adat pertama di Indonesia. AMAN juga menjadi salah satu agensi yang mendorong perubahan regulasi atas UU No.41/1999 tentang Kehutanan. Bersama dengan dua representasi masyarakat adat dari Kenegerian Kuntu, Kabupaten Kampar, Provinsi Riau; dan Kasepuhan Cisitu, Kabupaten Lebak, Provinsi Banten, AMAN mengajukan permohonan uji materiil atas UU Kehutanan tersebut di Mahkamah Konstitusi. Upaya tersebut menghasilkan tonggak baru arah advokasi masyarakat adat pada ranah hukum dengan keluarnya Putusan Mahkamah Konstitusi No.35/ PUU-X/2012 (kemudian disebut Putusan MK35).

Putusan MK 35 menjadi capaian progresif yang menyelesaikan miskonsepsi dari penetapan kawasan hutan di Indonesia. Putusan MK 35 mengoreksi kekeliruan UU Kehutanan, dengan memutuskan bahwa 'hutan adat adalah bukan lagi bagian dari hutan negara, tetapi merupakan bagian dari hutan hak'. Sebelumnya, Pemerintah Indonesia hanya melihat hutan adat sebagai areal yang berada di dalam hutan negara dengan mengacu pada UU No.41/1999 tentang Kehutanan. Baik di tingkat Pemerintah Pusat dan Pemerintah Daerah, regularisasi kebijakan mengenai masyarakat adat dan hutan adat terus mengalami perbaikan selama kurun waktu 2012-2016. Namun, perlu waktu lebih dari tiga tahun untuk mewujudkan pengakuan terhadap hutan adat di dalam kawasan hutan oleh Negara. Pada 30 Desember 2016, untuk pertama kali Pemerintah Indonesia mengakui 9 hutan adat dengan total luasan 13.121,99 hektar. Progress tersebut semakin bertambah hingga tahun 2017, terdapat 8 hutan adat yang telah diakui oleh pemerintah Indonesia, dan membuat total luas hutan adat yang diakui bertambah menjadi hampir 17.000 hektar.

Capaian tersebut muncul karena upaya jejaring masyarakat sipil untuk mendorong Kementerian Lingkungan Hidup dan Kehutanan (KLHK) menjadi arena diskresi yang efektif guna mempercepat penetapan hutan adat (lihat Safitri, Berliani, dan Suwito, 2015). Melalui Direktorat Jenderal Perhutanan Sosial dan Kemitraan Lingkungan, KLHK, menerbitkan Peraturan Menteri LHK No. P. 32/ Menlhk-Setjen/ 2015 tentang Hutan Hak yang menjadi salah satu dasar hukum penetapan hutan adat, dan memberikan jawaban terhadap kebuntuan proses pengakuan hutan adat di Indonesia (Malik, dkk, 2015). Permenlhk No.32/2015 juga menjadi wadah dalam mengakomodir sejumlah inisiatif pemerintah daerah yang telah menerbitkan beragam produk hukum daerah tentang pengakuan 
masyarakat adat dan penetapan wilayah serta hutan adatnya. Terlepas dari capaian penetapan hutan adat di atas oleh pemerintah Indonesia, sejumlah literatur telah memperlihatkan analisis atas pembelajaran dari penetapan Hutan Adat di Indonesia.

Myrna Safitri (2016) dalam tulisannya Dividing the Land: Legal Gaps in the Recognition of Customary Land in Indonesian Forest Areas, memperlihatkan bahwa terdapat tiga faktor utama yang menyebabkan keterlambatan pengakuan hutan adat di Indonesia, khususnya Pasca Putusan MK 35. Ketiga faktor tersebut terdiri dari: i) inkonsistensi hukum nasional terkait payung hukum pengakuan masyarakat adat dan wilayahnya; ii) masih bertahannya pola pikir di antara birokrat kehutanan yang memandang bahwa 'kawasan hutan' adalah hanya hutan negara; dan iii) kuatnya motivasi politik-ekonomi di antara pemerintah daerah untuk memprioritaskan alokasi lahan untuk investasi skala besar daripada pengakuan wilayah adat. Selain itu, Arizona, dkk (2017) dalam Outlook Produk Hukum Daerah tentang Masyarakat Hukum Adat 2017 mengidentifikasi tiga model pengakuan hutan adat yang menjadi pembelajaran penting dalam mendorong pengakuan hutan adat, yakni: i) pengakuan hutan adat yang berasal dari bukan kawasan hutan; ii) pengakuan hutan adat yang berasal dari kawasan hutan (negara); dan iii) pengakuan melalui pencadangan untuk dijadikan sebagai hutan adat. Kedua tulisan tersebut pada dasarnya melihat ragam faktor keberhasilan dan hambatan dari diskresi penetapan hutan adat di Indonesia. Namun, kedua tulisan tersebut belum memperlihatkan secara detail tentang dinamika dan kontestasi pada proses regularisasi yang dimainkan juga oleh jejaring masyarakat sipil dalam menciptakan perubahan terhadap: i) penetapan hutan adat; dan ii) pengelolaan kawasan hutan di Indonesia.

Tulisan ini akan menyampaikan ide bahwa proses regularisasi merupakan sebuah aktivitas yang terus berlanjut di dalam masyarakat (lihat Moore, 1983). Proses regularisasi menjadi kategori penting di dalam menciptakan perubahan pada masyarakat. Dengan memahami regularisasi sebagi sebuah proses (law as process), tulisan ini berupaya melihat proses sosial yang membentuk sebuah aturan, apa yang menyebabkan sejumlah perangkat hukum di tingkat nasional dan daerah dapat mendukung atau menolak masyarakat adat sebagai pelaku pengelola kawasan hutan yang berwawasan lingkungan? Bagaimana reinterpretasi dan 
perubahan regulasi dapat terjadi untuk mewujudkan percepatan penetapan hutan adat? Apa yang membuat jejaring masyarakat sipil berperan dalam mendorong masyarakat adat sebagai subjek pengelola utama kawasan hutan ${ }^{3}$ (baca: hutan adat) yang berwawasan lingkungan? Serta, bagaimana arena diskresi yang efektif dapat juga dimunculkan bukan hanya dalam fase mendorong penetapan hutan adat, tetapi juga mengisi agenda pasca penetapan hutan adat?

Tulisan ini juga dipersiapkan dalam momentum penting di akhir tahun 2017, dan memasuki tahun politik 2018, saat Pilkada serentak akan dilakukan. Selain itu momentum ini juga menguji komitmen pemerintahan saat ini, sebelum memasuki arena politik 2019 yang menjadi penghujung periode pemerintah Jokowi-JK. Komitmen Pemerintahan Jokowi-JK terhadap isu hutan adat dalam sembilan agenda pembangunan Nawa Cita menjadi tantangan yang harus dijawab dengan sejumlah capaian penetapan hutan adat oleh Pemerintah Indonesia guna mempertahankan konstituen presiden, yakni masyarakat adat. Tidak dipungkiri posisi masyarakat adat dan isu pengakuan hutan adat adalah arena politik baik di tingkat daerah dan nasional untuk memperoleh pengakuan secara hukum dalam pengelolaan kawasan hutan di Indonesia. Secara singkat tulisan ini dibagi ke dalam tiga bagian. Pertama adalah telaah singkat atas produk hukum daerah tentang pengakuan masyarakat hukum adat dan penetapan hutan adat hingga periode 2017 untuk menunjukkan sejumlah catatan penting selama hampir lima tahun keluarnya Putusan MK35. Bagian ini juga sekaligus memperlihatkan perubahan dan progress terkait peningkatan jumlah produk hukum daerah tentang masyarakat hukum adat dari tahun ke tahunnya; kedua adalah dinamika politik-hukum dalam mewujudkan posisi masyarakat adat sebagai pelaku utama pengelolaan kawasan hutan; dan ketiga adalah tantangan kedepan saat masyarakat adat dihadapkan pada agenda pasca penetapan hutan adat.

3 Berdasarkan istilahnya, UU No.41/1999 tentang Kehutanan membedakan antara 'hutan' dan 'kawasan hutan' . 'Hutan' adalah suatu kesatuan ekosistem berupa hamparan lahan berisi sumber daya alam hayati yang didominasi pepohonan dalam persekutuan alam lingkungannya, yang satu dengan lainnya tidak dapat dipisahkan (Pasal 1, ayat 2); sedangkan $k a-$ wasan hutan adalah wilayah tertentu yang ditunjuk dan atau ditetapkan oleh pemerintah untuk dipertahankan keberadaannya sebagai 'hutan tetap'. Hutan tetap berarti hutan yang tidak dapat diubah untuk peruntukkan tanah lainnya. Hingga saat ini Pemerintahan Indonesia masih belum berhasil dalam menetapkan hutan tetap.Hal itu terjadi proses pengukuhan kawasan hutan tidak dilakukan dengan sempurna. Lihat Safitri, 2015. Dividing the Land: Legal Gaps in the Recognition of Customary Land in Indonesian Forest Areas. Halm. 35-37. 
Studi tentang hukum yang dilakukan pada tulisan ini mengombinasikan beberapa metode, bukan hanya menginterpretasi muatan dari 215 produk hukum daerah, tetapi juga memperlihatkan refleksi penulis selama kurun waktu 2015-2017 saat arah advokasi hutan adat mulai membuahkan hasil. Refleksi tersebut diperoleh dengan mengikuti sejumlah proses regulariasi dalam lingkup penyusunan perundang-undangan terkait pengakuan Subjek Masyarakat Hukum Adat, Wilayah Adat dan Hutan Adat, serta Desa Adat; penyusunan Peraturan Menteri terkait Hutan Adat, dan dialog bersama Pemerintah Daerah dalam menyusun Peraturan Daerah dan Surat Keputusan Bupati atau Walikota, dan Gubernur tentang masyarakat hukum adat. Mengutip Sally Falk Moore (1978) dalam Law as Process, studi antropologi telah memberikan kontribusi terhadap studi tentang hukum, yakni memahami norma hukum dengan mengaitkannya pada dimensi 'waktu' dan 'konteks'. Menurut Moore, ada tiga hal dalam memahami munculnya sebuah aturan, pertama adalah relasi dari aturan yang ada terhadap faktor yang mendorong terbentuknya perilaku sosial; kedua adalah analisis historis tentang peristiwa apa yang mendorong terbentuknya sebuah aturan dan menjadi konsekuensi dari kondisi sebelumnya; ketiga adalah masalah konteks, jenis dan tingkatan hubungan sistematis antara suatu aturan dengan beberapa bagian lainnya dalam masyarakat secara sosio-kultural. Ketiga aspek tersebut merupakan dasar dari persoalan kausalitas yang mendorong terbentuknya sebuah aturan (Moore, 1978: 6-7).

\section{Progress Regularisasi tentang Masyarakat Hukum Adat Pasca Putusan MK 35: Dari produk hukum daerah hingga RUU Masyarakat Adat}

Putusan MK 35 yang dibacakan pada 16 Mei 2013 telah memberikan dampak pada pembaruan hukum di tingkat nasional, serta mendorong hadirnya berbagai produk hukum daerah mengenai masyarakat hukum adat. Setelah Putusan MK 35 terdapat 69 produk hukum daerah baru mengenai masyarakat hukum adat, mulai dari pengakuan terhadap keberadaan masyarakat hukum adat, wilayah adat, hutan adat, lembaga dan peradilan adat, serta desa adat (lihat Arizona, dkk, 2017). Sementara luas wilayah adat dari 15.199,16 hektar sebelum Putusan MK 35 menjadi 213.541,01 hektar. Artinya terjadi penambahan seluas 197.541,85 hektar 
dalam tiga tahun (2014-2016), terdapat 65.847,28 hektar setiap tahunnya. Menurut riset Epistema Institute tahun 2015-2017, meskipun telah banyak produk hukum daerah mengenai masyarakat hukum adat, tetapi belum banyak wilayah adat yang ditetapkan. Dari 215 produk hukum daerah tentang Masyarakat Hukum Adat yang telah diterbitkan sepanjang kurun waktu 1979-2017, terdapat 57 produk hukum daerah yang berkaitan dengan wilayah, tanah, hutan, dan sumber daya alam yang dikelola oleh masyarakat adat. ${ }^{4}$ Namun, hanya 21 produk hukum daerah yang menyebutkan luas dan menampilkan peta wilayah dengan keseluruhannya mencapai 13.558,02 hektar. Hal ini penting diperhatikan agar pengakuan terhadap masyarakat adat dan hak tradisionalnya bisa memiliki implikasi langsung terhadap pengakuan dan perlindungan wilayah, tanah, dan hutan adat.

Dari tahun ke tahun, jumlah produk hukum daerah mengenai masyarakat hukum adat terus meningkat. Hal tersebut dapat dilihat berdasarkan tahun 19791998; 5 produk hukum daerah, 1999-2008; 65, 2004-2012; 57, 2013-2016; 69, dan tahun 2017; 12 produk hukum daerah. Jika dibandingkan materi muatan produk hukum daerah sebelum dan Putusan MK 35, masing-masing lembaga adat, peradilan adat, dan hukum adat $65,51 \% ; 21,30 \%$, keberadaan masyarakat adat dan wilayah adat $8,6 \% ; 17,25 \%$, wilayah adat dan hutan adat $41,32 \% ; 18,26 \%$, desa adat $13,10 \% ; 9,13 \%$, dan lembaga pelaksanaan urusan masyarakat adat 1,1\%; 4,6\%.

Sebelum Putusan MK 35, ${ }^{5}$ wilayah adat yang ditetapkan melalui produk hukum daerah hanya seluas 15.199,16 hektar dan hutan adat seluas 10.097,31 hektar. Setelah 3 tahun Putusan MK 35 luas wilayah adat bertambah menjadi 197.541,85 hektar dan hutan adat seluas 6.451,74 hektar. Sehingga sampai tahun 2016, luas wilayah adat yang telah ditetapkan melalui produk hukum daerah seluas 212.741 hektar dan hutan adat seluas 16.549 hektar. Penetapan wilayah dan hutan adat mengalami peningkatan 12 kali lipat. Hal ini menunjukan signifikansi Putusan MK 35 dalam memperluas pengakuan terhadap wilayah dan hutan adat melalui produk hukum daerah.

Dari sisi jumlah produk hukum, sejauh ini antara sebelum dan setelah putusan MK 35 sama-sama terdapat 17 produk hukum daerah yang berisi mengenai

4 Malik, Arizona, Yance dan Muhajir, Mumu. “Analisis Trend Produk Hukum Daerah Mengenai Masyarakat Adat, (Jakarta: Policy Brief Epistema Institute Vol. 01/2015), hlm 7.

5 Lihat Outlook Epistema 2017, hlm. 7. 
wilayah adat dan hutan adat yang ditandai dengan peta maupun penyebutan luasnya. Namun, setelah Putusan MK 35, sebaran produk hukum daerah mengenai wilayah dan hutan adat semakin bertambah dan luasannya juga meningkat sangat signifikan di beberapa wilayah Indonesia.

Kontribusi masyarakat adat terhadap pengelolaan kawasan hutan adat yang berwawasan lingkungan juga diakomodir oleh beberapa Pemerintah Daerah melalui penerbitan Produk Hukum Daerah. Berdasarkan identifikasi data Produk Hukum Daerah selama kurun waktu 1979-2017, terdapat 53 Produk hukum daerah yang memiliki muatan tentang aspek Pengelolaan dan Perlindungan Lingkungan Hidup di dalam wilayah dan hutan adat. REDD, Pengelolaan Hutan Adat, Hutan Adat sebagai buffer zone dari Kawasan Konservasi, hingga model Konservasi Kemitraan, menjadi beberapa muatan yang diatur di dalam produk hukum daerah tersebut. Sejumlah bentuk pengetahuan lokal masyarakat dalam pengelolaan kawasan hutan berbasis konservasi masyarakat adat diformulasikan di dalam klausul pasal-pasal pada produk hukum daerah. Pasang ri Kajang di Hutan Adat Ammatoa Kajang, Bulukumba, Sulawesi Selatan; dan Tatali Paranti Karuhun di Hutan Adat Kasepuhan Karang, Lebak, Banten, merupakan beberapa ragam pengetahuan lokal masyarakat adat yang diakomodir di dalam produk hukum daerah untuk menjamin posisi mereka sebagai subjek utama pengelola hutan dan sumber daya alam di dalam hutan adat.

Namun, tidak terjadinya harmonisasi antara produk hukum daerah tentang masyarakat hukum adat dengan rezim undang-undang kehutanan saat ini, UU No.41/1999, memperlihatkan masih adanya perdebatan bahwa apakah masyarakat hukum adat dan hutan adatnya cukup diakui dan ditetapkan melalui 'Peraturan Daerah' atau 'produk hukum daerah'? Berdasarkan Pasal 67, ayat (1) huruf a, huruf b, huruf c, dan ayat (2), UU No. 41 Tahun 1999 tentang Kehutanan memperlihatkan bahwa 'Peraturan Daerah' menjadi satu-satunya mekanisme pengakuan eksistensi masyarakat adat.

“Masyarakat hukum adat sepanjang menurut kenyataannya masih ada dan diakui
keberadaannya berhak melakukan pemungutan hasil hutan untuk pemenuhan
kebutuhan hidup sehari-hari masyarakat adat yang bersangkutan, melakukan
kegiatan pengelolaan hutan berdasarkan hukum adat yang berlaku, dan berhak 
mendapatkan pemberdayaan dalam rangka meningkatkan kesejahteraannya. Pengukuhan keberadaan dan hapusnya masyarakat hukum adat ditetapkan dengan Peraturan Daerah". ${ }^{6}$

Padahal dari 215 produk hukum daerah yang telah diterbitkan untuk pengakuan MHA, penetapan wilayah adat, hutan adat, dan kampung adat atau desa adat, tidak semua berupa peraturan daerah, tetapi terdapat juga 44 produk hukum daerah berupa Keputusan Bupati, Keputusan Bersama, Keputusan Kepala Desa, dan Peraturan Gubernur. Besarnya biaya dan waktu dalam mendorong penerbitan Peraturan Daerah tentang Masyarakat Hukum Adat menjadi kendala yang dirasakan oleh masyarakat adat di Indonesia. Seperti Peraturan Daerah Kabupaten Lebak No.8/2015 tentang Pengakuan dan Perlindungan Masyarakat Adat Kasepuhan, setidaknya diperlukan waktu lebih dari tiga tahun untuk memperoleh pengakuan secara legal dari Pemerintah Kabupaten Lebak, Banten.

Pasal 67, UU No.41/1999 tentang Kehutanan memang menjadi salah satu pasal yang ditinjau kembali melalui Mahkamah Konstitusi, tetapi upaya tersebut tidak dikabulkan di dalam Putusan MK 35. UU Kehutanan ini merupakan perundangundangan di bidang sumber daya alam yang paling sering dilakukan Judicial Review (JR) ke Mahkamah Konstitusi (MK). Hingga saat ini terdapat sembilan kali JR terhadap UU Kehutanan ke MK, empat di antaranya dikabulkan oleh MK, yaitu Putusan Perkara No. 34/PUU-IX/2011, Putusan Perkara No. 45/PUUIX/2011, Putusan Perkara No 35/PUU-X/2012, dan Putusan Perkara No. 95/PUUXII/2014. ${ }^{7}$

6 Lihat Pasal 67 ayat (1) huruf a, huruf b, huruf c, dan ayat (2), UU No. 41 Tahun 1999 tentang Kehutanan.

7 Yance Arizona, Erasmus Cahyadi, dan Malik, Mengakhiri Rezim Kriminalisasi Kehutanan: Anotasi Putusan Mahkamah Konstitusi Nomor 95/Puu-XII/2014 Mengenai Pengujian Undang-Undang No. 18 Tahun 2013 Tentang Pencegahan dan Pemberantasan Perusakan Hutan, dan Undang-Undang No. 41 Tahun 1999 Tentang Kehutanan, (Jakarta: Epistema Institute dan AMAN, 2015), hlm. 14-16. 
Tabel 1. Ragam Putusan Mahkamah Konstitusi untuk Judicial Review terhadap UU No.41/ 1999 tentang Kehutanan

\begin{tabular}{|c|c|c|}
\hline No & $\begin{array}{c}\text { Nomor Putusan } \\
\text { Mahkamah } \\
\text { Konstitusi }\end{array}$ & Pasal yang ditinjau \\
\hline 1 & $\begin{array}{l}\text { Putusan MK } \\
\text { No. 34/PUU- } \\
\text { IX/2011 }\end{array}$ & $\begin{array}{l}\text { Pasal } 4 \text { ayat } 3 \text {, menjadi "Penguasaan hutan oleh negara } \\
\text { tetap memperhatikan hak masyarakat hukum adat, sepanjang } \\
\text { kenyataannya masih ada dan diakui keberadaannya, hak } \\
\text { masyarakat yang diberikan berdasarkan ketentuan } \\
\text { peraturan perundang-undangan, serta tidak bertentangan } \\
\text { dengan kepentingan nasional". Penguasaan kawasan hutan } \\
\text { oleh pemerintah tidak boleh dilakukan secara sewenang- } \\
\text { wenang sehingga menimbulkan kerugian terhadap } \\
\text { masyarakat hukum adat dan hak masyarakat berdasarkan } \\
\text { peraturan perundang-undangan. }\end{array}$ \\
\hline 2 & $\begin{array}{l}\text { Putusan MK } \\
\text { No. 45/PUU- } \\
\text { IX/2011 }\end{array}$ & $\begin{array}{l}\text { Pasal } 1 \text { angka } 3 \text { UU Kehutanan menjadi "Kawasan hutan } \\
\text { adalah wilayah tertentu yang ditumk ditetapkan } \\
\text { oleh Pemerintah untuk dipertahankan keberadaannya sebagai } \\
\text { hutan tetap". Perubahan ini menyebabkan kawasan hutan } \\
\text { yang baru selesai ditunjuk tidak memiliki legalitas sebagai } \\
\text { kawasan hutan sampai selesai dilakukan seluruh tahapan } \\
\text { pengukuhan kawasan hutan. }\end{array}$ \\
\hline 3 & $\begin{array}{l}\text { Putusan MK No. } \\
\text { 35/PUU-X/2012 }\end{array}$ & $\begin{array}{l}\text { Pasal } 1 \text { angka } 6 \text { UU Kehutanan menjadi "Hutan adat adalah } \\
\text { hutan yang berada dalam wilayah masyarakat hukum } \\
\text { Adat". Akibatnya, pemerintah harus mengembalikan dan } \\
\text { mengakui hutan adat yang telah ditunjuk atau ditetapkan } \\
\text { oleh pemerintah sebagai kawasan hutan. }\end{array}$ \\
\hline 4 & $\begin{array}{l}\text { Putusan MK } \\
\text { No. 95/PUU- } \\
\text { XII/2014 }\end{array}$ & $\begin{array}{l}\text { Pasal } 50 \text { ayat (3) huruf e dan huruf i UU Kehutanan } \\
\text { sebagai berikut "Setiap orang dilarang: e. menebang } \\
\text { pohon atau memanen atau memungut hasil hutan } \\
\text { di dalam hutan tanpa memiliki hak atau izin dari } \\
\text { pejabat yang berwenang, kecuali terhadap masyarakat } \\
\text { yang hidup secara turun temurun di dalam hutan } \\
\text { dan tidak ditujukan untuk kepentingan komersial; i. } \\
\text { menggembalakan ternak di dalam kawasan hutan yang } \\
\text { tidak ditunjuk secara khusus untuk maksud tersebut oleh } \\
\text { pejabat yang berwenang, kecuali terhadap masyarakat } \\
\text { yang hidup secara turun temurun di dalam hutan dan } \\
\text { tidak ditujukan untuk kepentingan komersial;" Putusan } \\
\text { ini mengakhiri kriminalisasi terhadap masyarakat yang } \\
\text { hidup di dalam hutan yang selama ini mengelola dan } \\
\text { mempertahankan wilayahnya. Hal ini sejalan dengan } \\
\text { Putusan MK No. 55/PUU-VII/2010 mengenai pengujian } \\
\text { ketentuan pidana dalam UU Perkebunan. Putusan ini } \\
\text { menyatakan bahwa dalam menghadapi konfik tenurial } \\
\text { harus terlebih dahulu diselesaikan secara perdata daripada } \\
\text { melakukan pendekatan represif melalui ketentuan pidana. }\end{array}$ \\
\hline
\end{tabular}


Arena Mahkamah Konstitusi menjadi ruang advokasi untuk proses perubahan regulasi yang lebih mendukung bagi masyarakat adat khususnya dalam pengelolaan kawasan hutan. Namun, tidak hanya melalui upaya judicial review di dalam Mahkamah Konstitusi, tetapi juga upaya lobbying di tingkat Kementerian/Lembaga dalam mendorong peraturan yang lebih operatif untuk percepatan penetapan hutan adat di Indonesia. Berdasarkan pengamatan penulis, Peraturan Menteri dan Peraturan Direktorat Jenderal menjadi dua bentuk aturan paling operasional untuk mengakomodir inisiatif pemerintah daerah yang telah menerbitkan produk hukum daerah tentang MHA, sekaligus mempercepat proses penetapan hutan adat. Kementerian Lingkungan Hidup dan Kehutanan menjadi institusi Negara yang paling proaktif dalam mendorong pengakuan masyarakat adat dan penetapan hutan adat jika dibandingkan dengan kementerian lainnya. ${ }^{8}$ Selama kurun waktu 2015-2017, terdapat tiga Peraturan Menteri (Peraturan Menteri LHK No.32/2015 tentang Hutan Hak, Peraturan Menteri LHK No. 83/2016 tentang Perhutanan Sosial), Peraturan Menteri LHK No.34/2017 tentang Pengakuan dan Perlindungan Kearifan Lokal dalam Pengelolaan Sumber Daya Alam dan Lingkungan Hidup yang juga mengatur praktik kearifan lokal dalam perlindungan dan pengelolaan lingkungan hidup dan Sumber Daya Genetik satu Peraturan Direktorat Jenderal PSKL No.P.1/PSKL/Set/Kum.1/2/2016 tentang Tata Cara Verifikasi dan Validasi Hutan Hak, serta Rancangan Peraturan Direktorat Jenderal Konservasi Sumber Daya Alam dan Ekosistem, KLHK tentang Kemitraan Konservasi yang akan diterbitkan di akhir tahun 2017 ini. Peraturan Menteri dan Peraturan Direktorat Jenderal di KLHK tersebut merupakan beberapa diskresi untuk menjawab kekosongan hukum di tengah upaya percepatan penetapan hutan adat di Indonesia. Sebagai contoh, Peraturan ini menjadi produk hukum Menteri yang melahirkan diskresi dengan menerima segala bentuk 'Produk Hukum Daerah' di Kabupaten atau Provinsi untuk dapat digunakan sebagai dasar dari pengakuan hutan adat di Indonesia.

8 Meskipun terdapat beberapa kementerian lainnya seperti Kementerian Dalam Negeri yang telah menerbitkan Permendagri No.52/tahun 2014 tentang Pedoman Pengakuan dan Perlindungan Masyarakat Hukum Adat, dan Kementerian Agraria dan Tata Ruang/ BPN juga telah menerbitkan Permen ATR No.10 Tahun 2016 tentang Tata Cara Penetapan Hak Komunal atas Tanah Masyarakat Hukum Adat dan Masyarakat yang Berada dalam Kawasan Tertentu. Namun, belum ada satupun eksekusi secara nyata dari kedua peraturan tersebut yang dirasakan oleh masyarakat adat. 


\subsection{Progress Penetapan Hutan Adat}

Pada tingkat nasional terdapat 13.097,99 hektar hutan adat yang ditetapkan Menteri Lingkungan Hidup dan Kehutanan pada 30 Desember 2016. Dengan demikian terdapat 1.713,99 hektar atau 9,6\% hutan adat ${ }^{9}$ yang ditetapkan melalui produk hukum daerah yang ditindaklanjuti oleh Kementerian lingkungan Hidup dan Kehutanan sekitar 5.700 Kepala Keluarga (KK). Genap10 bulan pasca penetapan hutan adat tepatnya tanggal 25 Oktober 2017, pemerintah kembali menetapkan 3,992 ${ }^{10}$ hektar hutan adat, antara lain: (1) Hutan adat di Desa Marena, Kecamatan Kulawi, Kabupaten Sigi, Sulawesi Tengah seluas 1.161 hektar; (2) Hutan adat di Desa Tapang Semedak, Kabupaten Sekadau, Kalimantan Barat seluas 41 hektar; (3) Hutan adat di Desa Juaq Asa, Kabupaten Kutai Barat, Kalimantan Timur seluas 49 hektar; (4) Hutan adat di Desa Batu Kerbau, Kabupaten Bungo seluas 323 dan 326 hektar; (5) Hutan adat di Desa Senamat Ulu, Kabupaten Bungo seluas 223 hektar; (6) Hutan adat di Desa Baru Pelepat, Kabupaten Bungo seluas 245 dan 821 hektar; (7) Hutan adat di Desa Ngaol, Kabupaten Merangin seluas 278 hektar; (8) Hutan adat di Desa Merangin, Kabupaten Merangin, Provinsi Jambi seluas 525 hektar. Kini kurang lebih terdapat 17.000 hektar hutan adat yang tersebar di beberapa wilayah di Indonesia yang telah ditetapkan oleh pemerintah. Menurut data Kementerian Sosial tahun $2017^{11}$, sebanyak 231.268 KK komunitas adat terpencil yang hidup di Indonesia. Dari 231.268 KK, sebanyak 123.977 KK sudah diberdayakan melalui penetapan hutan adat. Sedang 3.955 KK sedang diberdayakan. Sisanya belum diberdayakan $123.336 \mathrm{KK}$.

Konsekuensi menarik lainnya dari proses penetapan hutan adat selama kurun waktu 2016-2017 adalah perubahan status kawasan hutan dari 'hutan negara' menjadi 'hutan adat', ternyata memberikan ruang bagi masyarakat adat untuk menjadisubjek pengelola kawasan konservasi. Tiga hutan adat yang telah ditetapkan yakni, Hutan Adat Kasepuhan Karang di dalam kawasan Taman Nasional Gunung

9 Ibid, Outlook Epistema 2017, hlm. 10.

10 http://www.mongabay.co.id/2017/10/24/sembilan-komunitas-peroleh-penetapan-hutanadat/ diakses tanggal, 16 Oktober 2017.

11 https://nasional.sindonews.com/read/1249146/15/123-ribu-keluarga-adat-terpencil-di-indonesia-hidup-terbelakang-1508231965 diakses tanggal, 16 Oktober 2017. 
Halimun Salak, Hutan Adat Wana Posangke di dalam Cagar Alam Morowali, dan Hutan Adat Marga Serampas di dalam kawasan Taman Nasional Kerinci Seblat , berada di dalam kawasan konservasi. Perubahan status tersebut tidak serta merta mengubah fungsi kawasan hutan sebagai areal konservasi. Penyesuaian zonasi areal konservasi dilakukan oleh sejumlah birokrat Direktorat Jenderal KSDAE untuk menyesuaikan perubahan status kawasan hutan tersebut.

\subsection{Kontestasi Legislasi RUU Masyarakat Adat}

Ragam jalur advokasi juga diikuti dengan upaya menyusun Rancangan Undang-Undang tentang Masyarakat Adat di tingkat DPR. Salah satu draft versi AMAN dan jejaring masyarakat sipil pegiat masyarakat adat mengusulkan pembentukan Komisi Nasional Masyarakat Adat yang dibentuk oleh Presiden di tingkat pusat. Komisi tersebut kemudian menjalankan 10 peran terkait menjamin pengakuan hak masyarakat adat dan wilayahnya pada lebih dari dua provinsi, penyelarasan kebijakan pembangunan baik di pusat dan daerah untuk memerhatikanhakmasyarakatadat, melakukan penyelidikan terhadap pelanggaran hak-hak masyarakat adat, mediasi konflik yang melibatkan masyarakat adat, dan penyelesaian pelanggaran HAM berat di masa lalu yang melibatkan masyarakat adat. Wacana mendorong Undang-Undang tentang Masyarakat Adat sebenarnya telah muncul sejak tahun 2009, saat AMAN bersama beberapa NGO mendorong pembentukan tim yang bekerja pada draft Rancangan Undang-Undang Pengakuan dan Perlindungan Hak Masyarakat Hukum Adat (RUU PPHMHA) (lihat Arizona dan Cahyadi, 2013: 51). Namun, hingga akhir tahun 2017 belum ada progress signifikan terkait pengesahan RUU tentang Masyarakat Adat di tingkat DPR, meski RUU tersebut telah masuk menjadi prolegnas di tahun 2017. Lambatnya progress pembahasan RUU tentang Masyarakat Adat, sempat memunculkan rasa pesimis dari AMAN terhadap komitmen Pemerintahan Jokowi-JK. Komitmen RUU Masyarakat Adat merupakan salah satu agenda pembangunan Nawa Cita Jokowi-JK saat di awal pemerintahannya. Bahkan AMAN berencana untuk mencabut dukungan secara politik kepada Presiden Joko Widodo saat Pilpres 2019, jika komitmen tersebut tidak tercapai di penghujung periode pemerintahan saat ini (lihat Catatan Akhir Tahun AMAN, 2017). 
Meskipun demikian, beragam upaya dari proses regularisasi yang dilakukan di tingkat daerah, kementerian/lembaga, hingga nasional, ragam jalur advokasi gerakan masyarakat sipil untuk mendorong pengakuan terhadap masyarakat adat dan wilayah serta hutan adatnya telah membuahkan hasil. Isu pengakuan masyarakat adat tidak hanya sebatas pengakuan akan subjeknya, tetapi juga direplikasi ke dalam beragam opsi hukum terkait pengakuan wilayah adat-hutan adat, desa adat, kepercayaan yang dianut oleh masyarakat adat sebagai hak warga negara, dan hak komunal. Tidak dipungkiri bahwa dalam proses advokasi penetapan hutan adat, tidak ada cara tunggal untuk mendorong kehadiran Negara dalam menjamin hak bagi masyarakat adat. Dari kondisi tersebut, peran organisasi masyarakat sipil sangat signifikan dalam melakukan replikasi ke dalam beragam opsi pengakuan bagi masyarakat adat untuk menjadi loncatan ke arah pengakuan hutan adat di Indonesia. Bagaimana replikasi tersebut dapat terjadi? Dan bagaimana upaya percepatan pengakuan terhadap hutan adat tetap juga memastikan posisi masyarakat adat sebagai subjek yang tepat dalam mengelola kawasan hutan secara berwawasan lingkungan? Bagian selanjutnya akan menelaah dinamika politikhukum posisi masyarakat adat sebagai salah satu subjek pengelola kawasan hutan di Indonesia.

\section{Dinamika Politik-Hukum Posisi Masyarakat Adat sebagai Subjek Pengelola Kawasan Hutan di Indonesia}

Tahun 2017 menjadi momentum berarti bukan hanya terdapat pertambahan luas hutan adat yang ditetapkan oleh Pemerintah Indonesia, tetapi juga tahun 2017 terdapat ruang-ruang yang terbuka antara pemangku kebijakan untuk bersinergi dengan NGO dan masyarakat adat dalam mempercepat penetapan hutan adat di Indonesia. Sinergi tersebut terbuka dengan masuknya sejumlah aktor-aktor NGO di dalam diskusi perencanaan kebijakan Negara di tingkat Kementerian/ Lembaga hingga masuk ke dalam arena politik daerah dengan menjadi salah satu kandidat Gubernur atau Bupati, serta menjadi Tim Ahli di dalam Kantor Staf Kepresidenan (KSP).

Jauh sebelum capaian progress advokasi penetapan hutan adat ini, sebenarnya telah terdapat tiga rezim perundang-undanganyang menempatkan masyarakatadat 
sebagai subjek pengelola kawasan hutan sumber daya alam. Produk perundangan tersebut terdiri dari: i) UU No.41/1999 tentang Kehutanan; ii) UU No.32/2009 tentang Perlindungan dan Pengelolaan Lingkungan Hidup (PPLH); dan (iii) UU No.27 tahun 2008 jo. UU No.1 tahun 2014 tentang Pengelolaan Wilayah Pesisir dan Pulau-Pulau Kecil (UU PWP3K) (lihat Safitri, dkk, 2015; Uliyah, Wicaksono, Safitri, 2017). Pasca Putusan MK35 di tahun 2013, beberapa pasal di dalam UU Kehutanan telah mengalami perubahan, seperti Pasal 1 angka 6 yang sebelum putusan MK35 berisi "hutan adat adalah hutan negara yang berada dalam wilayah masyarakat hukum adat", menjadi "hutan adat adalah hutan yang berada dalam wilayah masyarakat hukum adat". Kedua, UU PPLH selanjutnya menuangkan beberapa asas kearifan lokal yang memperhatikan nilai-nilai luhur dalam Perlindungan dan Pengelolaan Lingkungan Hidup; dan pada Pasal 10 huruf (d) menjadikan dasar 'hak ulayat' dalam setiap penyusunan Rencana Perlindungan dan Pengelolaan Lingkungan Hidup baik oleh Menteri di bidang PPLH, gubernur atau bupati/ walikota (lihat Uliyah, Wicaksono, dan Safitri, 2017).

Tidak hanya pada sektor kehutanan, tetapi juga sektor wilayah pesisir melalui UU PWP3K telah mengakui posisi MHA sebagai salah satu kategori yang mengelola wilayah pesisir dan pulau-pulau kecil (Pasal 1, angka 34 dan angka 35, UU No. 1 Tahun 2014). Dengan demikian, MHA mempunyai wewenang untuk memanfaatkan dengan menerapkan hak ulayat laut mereka, tetapi tetap harus tunduk pada kepentingan nasional dan peraturan perundang-undangan. Pembahasan mengenai UU PWP3K ini penting untuk pengakuan terhadap penguasaan MHA atas hutan-hutan mangrove di wilayah pesisir ataupun kawasan hutan yang ada di pulau-pulau kecil. ${ }^{12}$ Dengan demikian, konteks hutan adat seharusnya tidak sekadar mengacu pada UU Kehutanan, tetapi juga merujuk UU PWP3K. Hal itu juga seharusnya berlaku di dalam rancangan UU Konservasi Keanekaragaman Hayati yang kini masuk menjadi salah satu agenda prolegnas di DPR. 


\section{Memperluas konteks pengakuan hutan adat di dalam kawasan konservasi}

Agenda menempatkan masyarakat adat sebagai subjek pengelola kawasan hutan juga dilakukan dengan mengenalkan konsep Kawasan Konservasi Masyarakat Adat ke dalam kebijakan negara. KKMA muncul sebagai wacana yang disampaikan secara global melalui Konvensi Keanekaragaman Hayati (Convention on Biological Diversity) yang telah mengakui Areal Konservasi Kelola Masyarakat (AKKM atau ICCAs). Secara definisi AKKM adalah bentuk pengakuan terhadap praktik konservasi oleh masyarakat yang terdiri dari 3 (tiga) aspek yang tidak bisa dipisahkan, yakni: lingkungan dan konservasi, budaya, dan ekonomi mata pencahariaan (Eghenter, 2016:13). Working Group ICCAs (Indigenous Peoples' and Community Conserved Territories and Areas) Indonesia memainkan peran dalam mengkampanyekan konsep KKMA dengan kolaborasi antara NGO pegiat masyarakat adat dan WWF pasca dilaksanakan Simposium mengenai ICCA di CIFOR, Bogor (Eghenter, 2017). Badan Registrasi Wilayah Adat (BRWA) yang masuk ke dalam WGII tersebut berperan sebagai Koordinator konsorsium WGII. Melalui data spasial BRWA menunjukkan bahwa terdapat lebih dari 6,28 juta hektar dari total 9,3 juta luas wilayah adat yang telah dipetakan, bertumpang tindih dengan kawasan hutan. 1,6 juta wilayah adat tersebut di antaranya berlokasi di kawasan konservasi (Widodo, 2016:9).

Secara perlahan inisiatif yang muncul dari peran WGII berupa 9,3 juta hektar wilayah adat yang dipetakan diakomodir oleh Kementerian Lingkungan Hidup dan Kehutanan, serta Badan Informasi Geospasial (BIG). BIG dengan mengacu pada Peraturan Presiden No. 9/2016 tentang Percepatan Pelaksanaan Kebijakan Satu Peta, telah mengakomodir dengan menginisiasi penyusunan standar pelibatan masyarakat adat dalam: i) membuat; dan ii) memverifikasi dan validasi peta wilayah adat untuk penetapan wilayah adat di seluruh Indonesia. Inisiasi tersebut dilakukan pasca dilakukan rapat koordinasi yang dimotori oleh Menteri Lingkungan Hidup dan Kehutanan, Ibu Siti Nurbaya, bersama Kemen ATR, Kemendagri, dan BIG, guna percepatan penetapan hutan adat di Indonesia.

12 Lihat Myrna Safitri, H. Berliani dan Suwito. “Penetapan Hutan Adat: Interpretasi Hukum dan Diskresi," dalam Partnership Policy Paper No. 7/2015. (Jakarta: Kemitraan). Halm. 1213. 
28 Desember 2017 juga sekaligus menutup capaian akhir tahun dalam mereplikasi pengakuan hutan adat di dalam kawasan konservasi. Setelah sekian lama masyarakat adat menjadi subjek yang selalu dikriminalisasi di dalam kawasan konservasi, upaya menempatkan masyarakat adat sebagai pelaku konservasi dilakukan dengan merancang satu Perdirjen tentang Konservasi Kemitraan. Melalui Direktorat Jenderal Konservasi Sumber Daya Alam dan Ekosistem (KSDAE), KLHK, draft Peraturan Dirjen KSDAE tentang Konservasi Kemitraan dirancang untuk menempatkan Kawasan Konservasi Masyarakat Adat sebagai salah satu klausul yang diatur untuk mendorong model konservasi yang lebih inklusif dengan melibatkan aktor lain selain Negara sebagai pengelola kawasan konservasi. KKMA mengutip istilah yang digunakan oleh Dirjen KSDAE, Ir. Wiratno, merupakan salah satu 'Cara Baru Kelola Kawasan Konservasi' yang mempertimbangkan prinsip-prinsip penghormatan terhadap Hak Asasi Manusia. Berbagai permasalahan yang menyangkut hubungan masyarakat atau masyarakat hukum adat di dalam kawasan konservasi diselesaikan melalui pendekatan non litigasi dan mengutamakan dialog. Biaya untuk menjaga kawasan konservasi juga dapat dikelola secara efektif saat petugas kawasan konservasi dapat menjaga wilayahnya bersama-sama masyarakat adat. Beberapa kasus di Taman Nasional Gunung Halimun Salak (TNGHS), Lebak Banten, memperlihatkan dari satu resort Gunung Bongkok yang tersebar di 11 desa seluas 6.000 hektar hanya dijaga oleh 12 petugas Taman Nasional. Padahal, sejumlah inisiatif dari Masyarakat Adat Kasepuhan telah memberlakukan ronda leuweung (patroli hutan) untuk memastikan kawasan konservasi TNGHSaman dari perambah kayu illegal.

Inisiatif masyarakat adat kasepuhan tersebut hanya menjadi satu contoh dari Cara Baru Kelola Kawasan Konservasi. Cara baru yang dilakukan melalui pelibatan masyarakat di \pm 5.860 Desa yang berada di pinggir atau di dalam kawasan konservasi seluas 27,2 Juta Ha. Upaya ini sekaligus memperlihatkan keseriusan Negara dalam merespons dua isu pada kawasan konservasi: i) kriminalisasi masyarakat adat dalam kawasan hutan; dan ii) jaminan akses kelola masyarakat adat di dalam konservasi yang lebih inklusif. Masyarakat diposisikan sebagai subyek atau pelaku utama dalam berbagai model pengelolaan kawasan, pengembangan daerah penyangga melalui ekowisata, pemanfaatan Hasil Hutan 
Bukan Kayu (HHBK), jasa lingkungan, patroli kawasan, penjagaan kawasan, restorasi kawasan, pengendalian kebakaran, budidaya dan penangkaran satwa.

Beragam upaya di atas menjadi sejumlah perubahan yang terjadi dalam sektor peraturan untuk mendorong masyarakat adat sebagai salah satu subjek pengelola kawasan hutan kedepannya. Tidak dipungkiri, bahwa isu masyarakat adat dan hutan adat menjadi persoalan politik, saat pemerintah Jokowi-JK telah menyebutkan bahwa jumlah luas hutan adat yang akan diverifikasi dan ditetapkan seluas 5.080.000 hektar dalam Nawa Cita yang telah diadopsi ke dalam RPJMN periode 2015-2019 (Catatan Akhir Tahun AMAN, 2017). Bagi Pemerintahan Jokowi-JK saat ini, diperlukan ragam cara untuk mempercepat pengakuan hutan adat guna mencapai target tersebut di penghujung masa pemerintahannya. Upaya kolaborasi bersama jejaring masyarakat sipil dan masyarakat adat menjadi satusatunya cara yang dapat dilakukan untuk merancang proses penetapan hutan adat yang lebih inklusif hingga akhir tahun 2019.

\section{Kesimpulan dan Tantangan Kedepan bagi Gerakan Advokasi Hutan Adat}

Jalan panjang pengakuan masyarakat adat di Indonesia telah memberikan beragam pelajaran untuk memperbaiki pengelolaan kawasan hutan. Mahalnya proses regulasisasi pengakuan masyarakat adat dan penetapan hutan adat melalui Peraturan Daerah telah disiasati dengan beragam proses regularisasi untuk menghasilkan diskresi yang efektif guna percepatan hutan adat di Indonesia. Namun, apa yang perlu diperhitungkan untuk memperkuat prospek pengelolaan kawasan hutan berbasis masyarakat adat di masa depan?

Secara kelembagaan, khususnya dalam mendorong RUU Masyarakat Adat, tantangan Indonesia saat ini adalah bagaimana memitigasi kesewenangan dalam kekuasaan pada organisasi yang dibentuk untuk mendukung masyarakat adat dan apa bentuk organisasi serta mekanisme yang dapat meyakinkan bentuk efektif pada proses pengakuan dan perlindungan keragaman masyarakat adat di Indonesia. Kedua, dalam persoalan politik anggaran, dari sekian jalur pengakuan MHA itu tidak diikuti dengan anggaran yang memadai. Sehingga tidak jarang implementasi dari pengakuan tersebut menjadi terhambat. Keseriusan 
pemerintah dalam menetapkan hutan adat hingga saat ini masih sangat minim. Salah satunya, anggaran untuk identifikasi, verifikasi, dan penetapan hutan adat di tahun 2018 hanya Rp. 1 miliar. Hal tersebut terlihat dalam pagu indikatif 2018 untuk diajukan dalam RUU Anggaran Pendapatan dan Belanja Negara (RAPBN) 2018. Besar anggaran terus menurun, dimana tahun 2016 Rp. 1,7 miliar dan tahun 2017 Rp. 1,4 miliar. ${ }^{13}$ Bagaimana bisa percepatan penetapan hutan adat dapat tercapai jika tidak didukung oleh persiapan politik anggaran yang kuat? Ketiga, dalam aspek legislasi, bahwa masih terdapat pekerjaan rumah berupa sekitar 32 rancangan peraturan daerah tentang masyarakat hukum adat yang masih belum terselesaikan, serta RUU Masyarakat Adat yang belum disahkan menjadi undangundang hingga penghujung tahun 2017. Sinergi seperti yang telah diinisiatifkan oleh jejaring masyarakat sipil pada WG ICCAs Indonesia dapat menjadi contoh bahwa pentingnya kerja secara kolaborasi untuk mendorong sebuah produk hukum guna memberikan kepastian bagi arah pengakuan masyarakat adat. Hal itu penting untuk diperhitungkan oleh Pemerintahan Jokowi-JK, jika masih ingin mempertahankan masyarakat adat sebagai salah satu konstituennya dalam Pilpres 2019.

13 Roy Salam Direktur Eksekutif Indonesia Budget Center (IBC), Anggaran Minim, Program DIpertanyakan, (Kompas: Jumat, 14 Juli 2017). 


\section{Daftar Pustaka}

Arizona, Yance, Cahyadi, Erasmus dan Malik. 2015. “Mengakhiri Rezim Kriminalisasi Kehutanan: Anotasi Putusan Mahkamah Konstitusi Nomor 95/Puu-XII/2014 Mengenai Pengujian Undang-Undang No. 18 Tahun 2013 Tentang Pencegahan dan Pemberantasan Perusakan Hutan, dan Undang-Undang No. 41 Tahun 1999 Tentang Kehutanan," Jakarta: Epistema Institute dan AMAN 2015.

Arizona, Yance, Malik, Ishimora L. Irene. 2017. "Pengakuan Hukum Terhadap Masyarakat Adat: Trend Produk Hukum Daerah dan Nasional Pasca Putusan MK 35/PUU-X/2012," Jakarta: Epistema Institute 2017.

Arizona, Yance., and Cahyadi, Erasmus 2013. 'The Revival of Indigenous Peoples: Contestations over Special Legislation on Masyarakat Adat', in Hauser-Schàublin, Brigitta (Ed). Adat and Indigeneity in Indonesia: Culture and Entitlements between Heteronomy and Self-Ascription. Gottingen University Press: p.43-62.

Arumingtyas, Lusia. Pemerintah Tetapkan Lagi sembilan Hutan Adat, http://www. mongabay.co.id/2017/10/24/sembilan-komunitas-peroleh-penetapan-hutanadat/, diakses tanggal, 16 Oktober 2017.

Eghenter, C. 2016. 'Catatan AKKM dan Jasa Ekosistem' dalam Tinjauan Kritis Atas RUU Konservasi Keanekaragaman Hayati dan Ekosistem. Bogor: Working Group ICCAs Indonesia.

Eghenter, C. 2017. Tenure Rights in Conservation Areas: Recognition and Role of Indigenous Peoples and Local Communities. Tulisan dipersiapkan dalam diskusi Panel 5 tentang Hak Masyarakat dalam Areal Konservasi, Pra-Konferensi Tenure, Oktober 2017.

Kurniawan, Hasan. 123 Ribu Keluarga Adat Terpencil di Indonesia Hidup Terbelakang, https://nasional.sindonews.com/read/1249146/15/123-ribu-keluarga-adatterpencil-di-indonesia-hidup-terbelakang-1508231965, diakses tanggal, 16 Oktober 2017. 
Malik, Arizona, Yance dan Muhajir, Mumu. 2015. "Analisis Trend Produk Hukum Daerah Mengenai Masyarakat Adat," Jakarta: Policy Brief Epistema Institute Vol. $01 / 2015$.

Moore, Sally F. 1983. Law as Process: An anthropological approach. London: Routledge. Safitri, Myrna. 2015. 'Dividing the Land: Legal Gaps in the Recognition of Customary Land in Indonesian Forest Areas' in Kasarinlan: Philippine Journal of Third World Studies 2015-16 30 (2)-31 (1): p.31-48.

Safitri, Myrna. 2015. Indigenous peoples in ASEAN: Indonesia. Chiang Mai: AIPP Foundation.

Safitri, Myrna., Berliani, H., dan Suwito. 2015. "Penetapan Hutan Adat: Interpretasi Hukum dan Diskresi," Partnership Policy Paper No. 7/2015. Jakarta: Kemitraan

Uliyah, L., Wicaksono, M.T., dan Safitri, M. 2017. Kontinuitas dan Transformasi Hukum Adat di Tengah Kebutuhan Hukum Konservasi Keanekaragaman Hayati di Indonesia. Jakarta: Winrock Internasional. Inpress. Tulisan dipersiapkan sebagai materi 'Konservasi dan Masyarakat Hukum Adat' pembahasan RUU Konservasi Sumber Daya Alam Hayati dan Ekosistem.

Widodo, Kasmita. 2015. 'Pengakuan AKKM dalam Kawasan Konservasi' dalam Tinjauan Kritis Atas RUU Konservasi Keanekaragaman Hayati dan Ekosistem. Bogor: Working Group ICCAs Indonesia. 